\title{
Morphological Assessment of Vascular Anastomoses Performed Using High Frequency Electric Welding
}

\author{
Evaluación Morfológica de Anastomosis Vasculares Realizada \\ Mediante Soldadura Eléctrica de Alta Frecuencia
}

\author{
Muzychenko P. F. ${ }^{1}$; Chernyak V. A. ${ }^{2}$; Savosko S. I. ${ }^{3}$; Lankin Yu. N. ${ }^{4}$; Karpenko K. K. ${ }^{5}$; Dubenko D. E. ${ }^{1}$; \\ Nahaliuk Yu. V.5; Zorgach V. U.6; Manzuk T. I. ${ }^{6}$; Gybalo R. V. ${ }^{5}$ \& Koshevskiy U. I. ${ }^{2}$
}

\begin{abstract}
MUZYCHENKO, P. F.; CHERNYAK, V. A.; SAVOSKO, S. I.; LANKIN, YU. N.; KARPENKO, K. K.; DUBENKO, D. E.; NAHALIUK, YU. V.; ZORGACH, V. U.; MANZUK, T. I.; GYBALO, R. V. \& KOSHEVSKIY, U. I. Morphological assessment of vascular anastomoses performed using high frequency electric welding. Int. J. Morphol., 39(4):1183-1189, 2021.

SUMMARY: The studies of the properties of vascular structures and tissues during electric welding, in particular direct morphological changes in the blood vessel walls in the areas of welding processes, are of interest. Perforating veins, femoral veins, abdominal aorta, vena cava and porcine perforating veins of the limbs were used in this study. We performed end-to-end electric welding of the aorta, venous end-to-side electric welding, vein end-to-artery side arterial and venous welding, venous end-to-end electric welding, as well as arterial and venous lumen sealing.The results of histological studies showed the formation of a coagulated acellular protein matrix, represented by unorganized denatured protein fibrous structures. In the area of vascular tissue coagulation, lacunes were formed as a result of water evaporation from the biological tissue. In the perifocal area of the welded junction, cell reduction occurred without necrosis or charring. The data obtained confirm the safety of high frequency electric welding of the main vessels and the prospectfor clinical use of the studied techniques.
\end{abstract}

KEY WORDS: Blood vessels; Anastomosis; High frequency welding technologies; Coagulation; Structure; Histology.

\section{INTRODUCTION}

In the past 15-20 years, high frequency electrocoagulation or "electric welding" of biological tissues has become one of the promising surgical techniques (Han et al., 2015; Podpriatov et al., 2018). Electric welding has gained a strong position in medicine due to its tissuepreserving effect and insignificant destructive effects on the living tissues, which allows for simultaneous incision and coagulation practically without any damage to the tissue morphological structure (Marinsky et al., 2016; Muzychenko et al., 2016; Marinsky et al., 2021). At the same time, the details of vascular welding and electrocoagulation technique remain unknown (Tryliskyy et al., 2018; Chernyak et al., 2019a).

The soft biological tissues, blood vessels in particular, are composite materials with a wide range of properties of their components. They consist of the cells, fibrous proteins of the extracellular matrix (collagen, elastin, fibronectin), connective tissue and extracellular fluid, which is an aqueous electrolyte. For a better understanding of the processes occurring during resistance welding of biological tissues, the properties and contribution of each component to the process should be determined. When the electric current flows through the tissue, heat is generated, which is proportional to the electric power and the time of current flow. Therefore, in high frequency welding of biological tissues, their heating is of key importance. Therefore, knowledge of tissue temperature in the welded junction is extremely important for the study of all aspects of welding.

The purpose of this study was to investigate the use of high frequency electric welding of the main arteries and veins in experimental animals, domestic pigs in particular.

\footnotetext{
${ }^{1}$ Department of Operating Surgery and Topographic Anatomy, Bogomolets National Medical University, Ukraine.

${ }^{2}$ Taras Shevchenko National University of Kyiv, Ukraine.

${ }^{3}$ Department of Histology and Embryology, Bogomolets National Medical University, Ukraine.

${ }^{4}$ E.O. PatonInstitute of Electric Welding of the NAS of Ukraine, Ukraine.

${ }^{5}$ National Military Medical Clinical Center "Main Military Clinical Hospital", Ukraine.

${ }^{6}$ Security Service of Ukraine, Military Medical Department, Ukraine.
} 
MUZYCHENKO, P. F.; CHERNYAK, V. A.; SAVOSKO, S. I.; LANKIN, YU. N.; KARPENKO, K. K.; DUBENKO, D. E.; NAHALIUK, YU. V.; ZORGACH, V. U.; MANZUK, T. I.; GYBALO, R. V. \& KOSHEVSKIY, U. I. Morphological assessment of vascular anastomoses performed using high frequency electric welding. Int. J. Morphol., 39(4):1183-1189, 2021.

\section{MATERIAL AND METHOD}

This experimental study was performed on porcine main arteries and veins: aorta, iliac arteries and veins, vena cava and perforating veins of the extremities. Storage and transportation conditions of macropreparations of the vessels: temperature $+5^{\circ} \mathrm{C}$, less than 2 hours.

The experimental procedures were performed in 3 steps: 1) free parts of the aorta were welded end-to-end and its small branches were sealed; 2) free parts of the vein were welded end-to-end; free parts of the vein were welded end-to-side; free parts of the artery and the vein were welded vein end-to-artery side; 3 ) the perforating veins were sealed using a specially designed endoscopic electrosurgical clamp.

Electric welding of the main vessels was performed using a power supply, Patonmed EKVZ-300 (Ukraine) (Fig. 1).

The main technological parameter of resistance welding of the soft biological tissues is the intensity of current flowing through the tissue. Electrical conductivity of biological tissues is determined by biological fluids (electrolytes) contained in the tissues - intracellular and extracellular fluids, blood and lymph, which make up $86 \%$ of total body weight.

For this study, a system to measure temperatures was created (Fig. 2), which consisted of a thermo-EMF amplifier (2:2), an external ADC module E14-440, L-Card (2: 3) and a laptop with the PowerGraph software (2: 4). Bipolar electrosurgical forceps (2: 5) and an EK-300M1 HF electric coagulator (2: 6) were also used.

To study the temperature range of $40-200{ }^{\circ} \mathrm{C}$, which is used for welding of biological tissues, we chose the K-type thermocouples with a diameter of $70 \mathrm{~mm}(2: 1)$.

A thermocouple was placed between the biological tissues in the area of current passage of the bipolar welding tool (Figs. 3 and 4).

Light Microscopy. Vessels were fixed in $10 \%$ phosphate buffered formalin $\left(24\right.$ hours, $4^{\circ} \mathrm{C}$ ), dehydrated in isopropanol ( 4 series $\times 1$ hour)and embedded in paraffin ( 3 series $\times 1$ hour). $8 \mu \mathrm{m}$ slices were cut with ThermoMicrom HM 360 microtome (ThermoScientific, USA). Deparaffinized slices stained by Hematoxylin and Eosin (H\&E) and Picro Sirius Red (PSR)

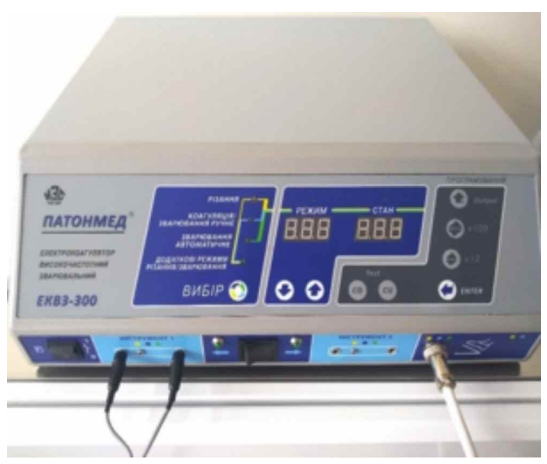

(Wegner et al., 2017), dehydrated and mounted in the medium (Merck, Germany). The micro preparations were studied on an Olympus BX51 microscope and obtained micrographs at a magnification of $\times 40, \times 200, \times 400$.

Fig. 1. Power supply of the electric welding device Patonmed EKVZ300 .

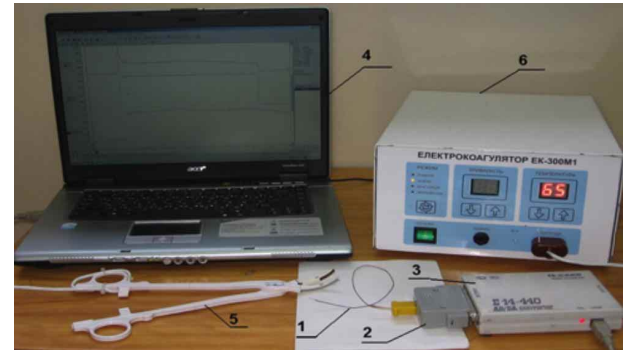

Fig. 2. Temperature measurement system for bipolar high frequency welding of the soft biological tissues. 1 - K-type thermocouples with a diameter of $70 \mathrm{~mm} ; 2$ - thermos-EMF amplifier; 3 - L-Card; 4 - laptop with the PowerGraph software; 5 - bipolar electrosurgical forceps; 6 - EK300M1 HF electric coagulator.

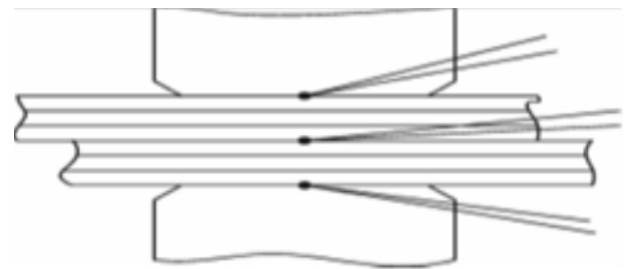

Fig. 3. Options for thermocouple locations between the jaws of a bipolar welding tool.

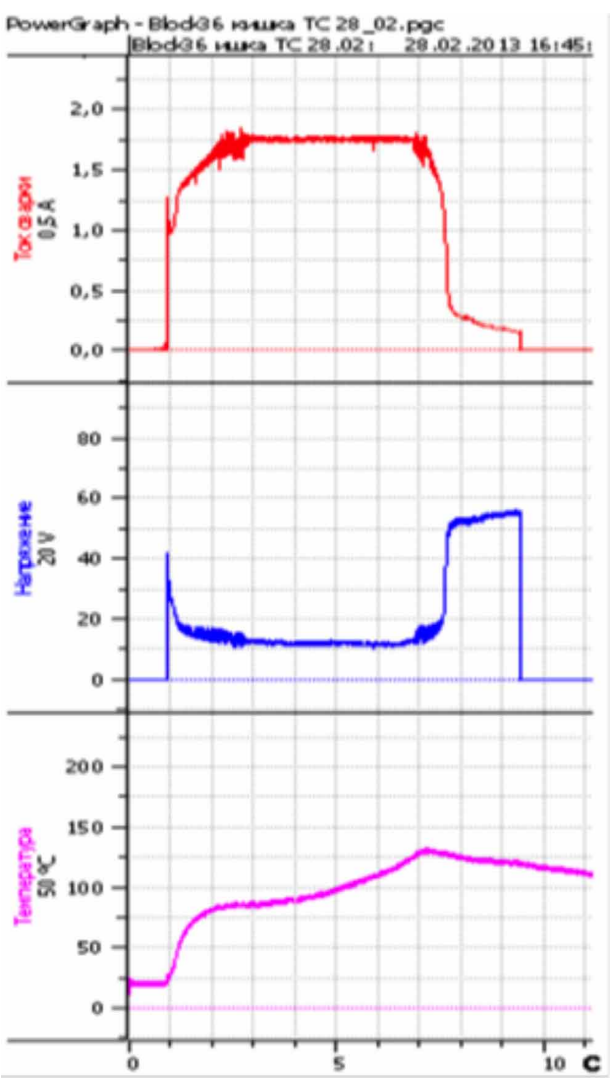

Fig. 4. The ratio of amperage, voltage and resistance and their fluctuations, depending on intestinal, muscle, lung and liver tissue heating. 


\section{RESULTS}

A histological study of the blood vessel wall after electric welding was carried out. The results of this study are presented in each case, that is, the immediate results of the welded vascular junctions.

\section{End-to-end welding of the aor-} ta. When the aorta was electrically welded, a change in the morphology of the membrane was observed in the wall of the damaged vessel (Figs. 5a,b). In case of an intact segment, tunica media had the biggest thickness and a significant number of elastic membranes and the smooth muscle cells between them ( $\mathrm{sin}$ gle nuclei were registered) (Fig. $5 c)$. In contrast to the intact vessel, the electric welding area was characterized by a sharp reduction in cellular elements and disorganization of fibrous elements; only single nuclei of the smooth muscle cells were registered, and the blood vessel wall was a coagulated protein matrix (Fig. 5d).

Arterial welding. The arterial wall after welding was characterized by a sharp narrowing of the vascular lumen, until complete closure (Fig. 6a). In the coagulation area, the appearance of empty lacunes was recorded, mainly in the muscular layer (tunica media), with a loss of cellular elements and disorganization of fibrous structures (elastic membranes) (Fig. 6b). The tunica adventitia also underwent similar changes; the outer contour of the adventitia was heterogeneous (from thinning to atypical thickening).
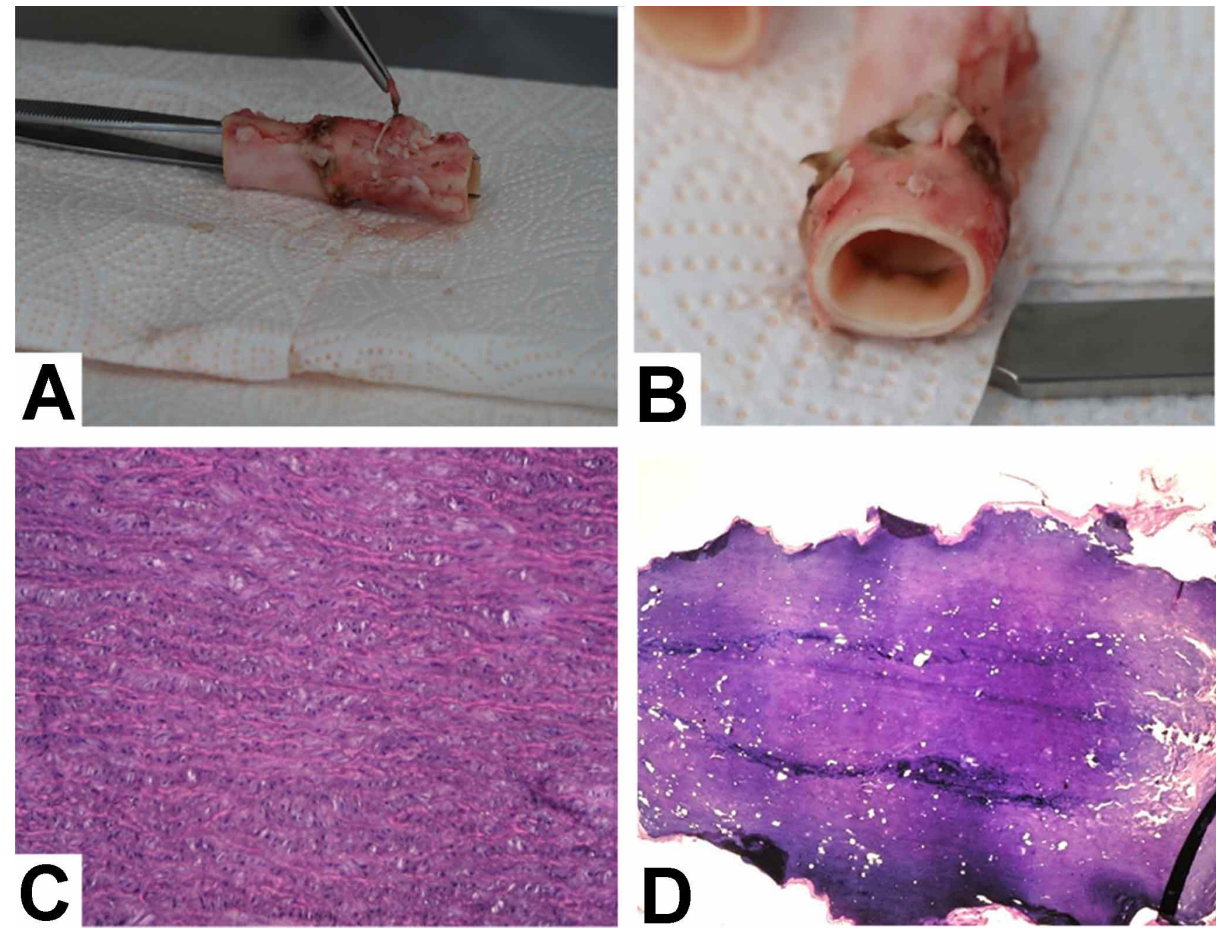

Fig. 5. The results of end-to-end aortic welding: a) aortic welding process; b) final appearance of the welded aorta from outside and from inside; c) intact aortic segments, intact vascular structure, cellular nuclei and elastic membranes of the tunica media are clearly recorded (hematoxylin-eosin, $\times 200$ ); d) electrically welded aortic segments; protein matrix (coagulation area) and single cellular nuclei only are recorded in the blood vessel walls; empty lacunes are formed (hematoxylin-eosin, $\times 40$ ).

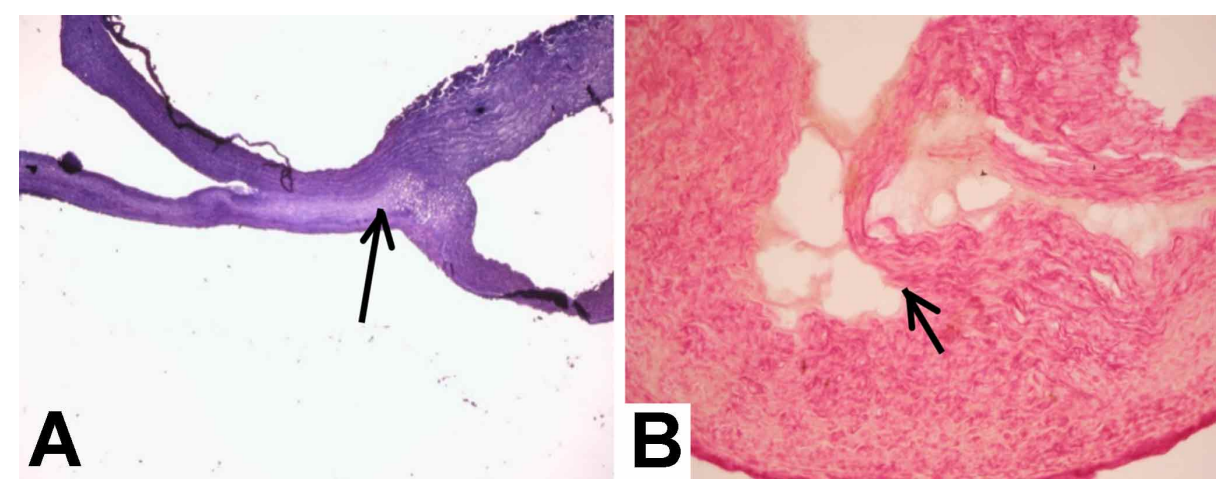

Fig. 6. The results of electric welding of the artery: a) narrowing of the lumen of the blood vessel in the area of welding (hematoxylin-eosin, $\times 40$ ); b) coagulation area and formation of empty lacunes in the muscular membrane (picrosirius red, $\times 200$ ).
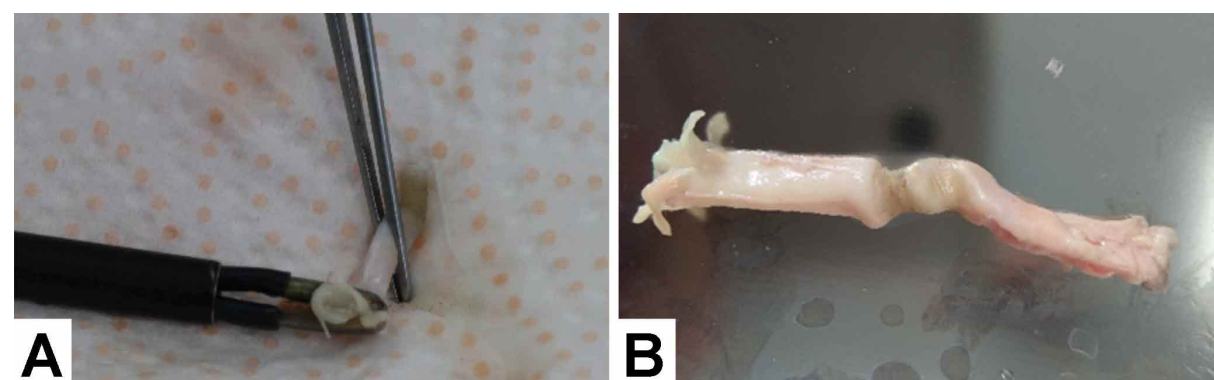

Fig. 7. The results of venous electric welding: a) process of perforating vein welding with a developed endoscopic electrosurgical clamp; b) final appearance of the welded perforating vein. 
Venous welding. The veins after welding had a deformation of the contour (Figs. 7a,b) and morphology was characterized by a narrowing of the lumen, thinning of the vessel wall, coagulation of the tunica media and adventitia. The cell reduction and lacunes were also detected as in the arterial wall. Venous end-to-side welding. An intact venous segment and coagulation area were recorded in the end-to-side welding area (Figs. 8a,b). When all the main structural elements of the blood vessel wall (intima, muscular layer, adventitia) were found in the intact area (Fig. 8c), in the welding area, the muscle layer was severely damaged with coagulation of fibrous structures into an almost homogeneous acellular matrix, and the intima contour was not observed at all. There were empty lacunes in the muscular and adventitial membranes (Fig. 8d).

\section{Arterial and venous vein end- to-artery sidewelding. A} vascular coagulation area was found in the area of arterial and venous welding (Fig. 9a, b). The thickness and structural organization of the vessels were changed at the level of welding. In the intact artery and vein, the main vascular membranes (intima, muscle membrane, adventitia) were clearly recorded (Fig. 9c); in the welding area, the structural elements of the blood vessel wall were disorganized, there was a multidirectional orientation of elastic fibers in the artery (circular in the intact area) and structurally impaired adventitia (areas of destruction, apparently after mechanical impact) (Fig. 9d). Acellular empty lacunes were recorded in the coagulation area.
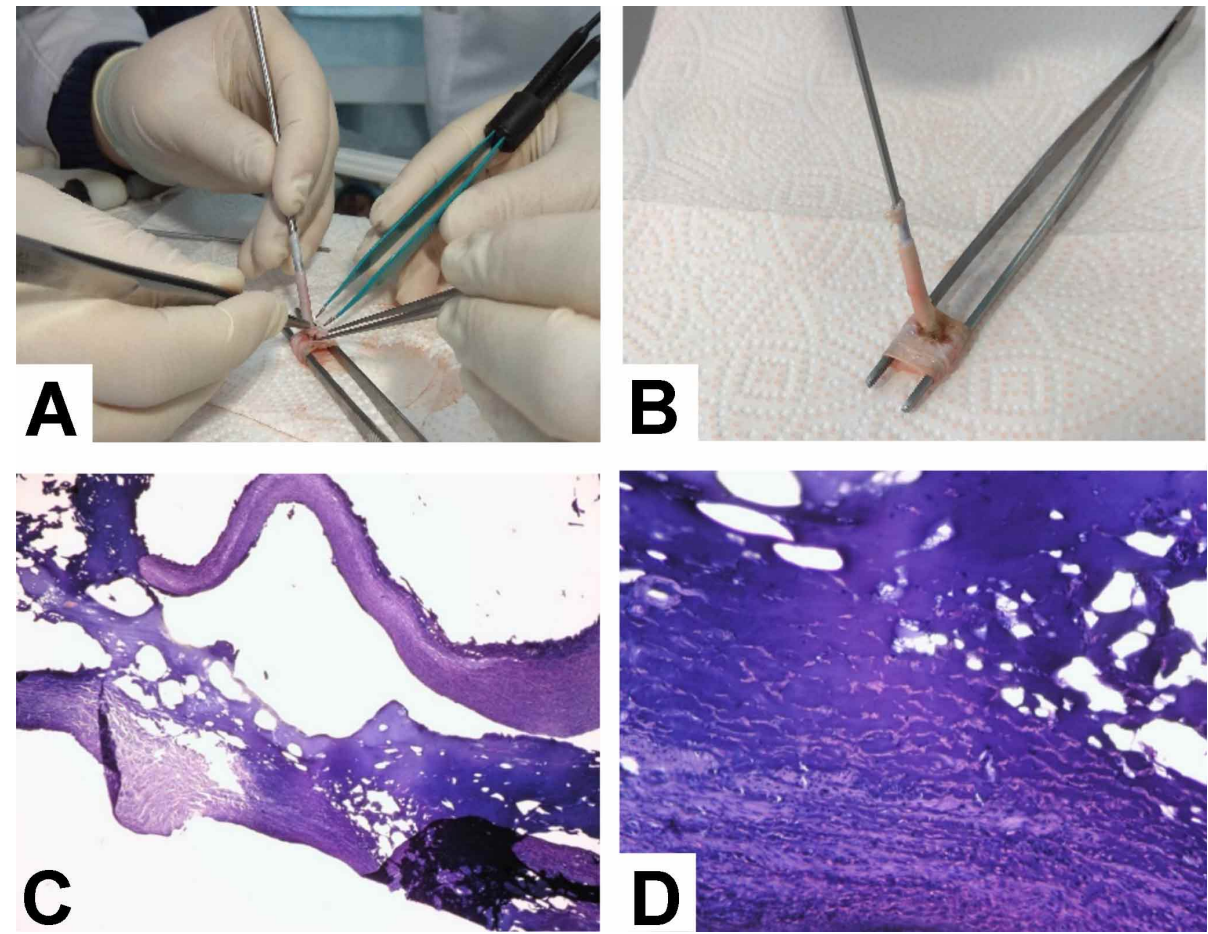

Fig. 8. The results of venous electric welding after end-to-side welding: a) process of venous welding with electrosurgical forceps; b) final appearance of the welded vein; c) longitudinal section of the vein at the level of welding (hematoxylin-eosin, $\times 40$ ); $\mathrm{d}$ ) welding area with matrix in the muscular membrane (hematoxylin-eosin, $\times 200$ ).
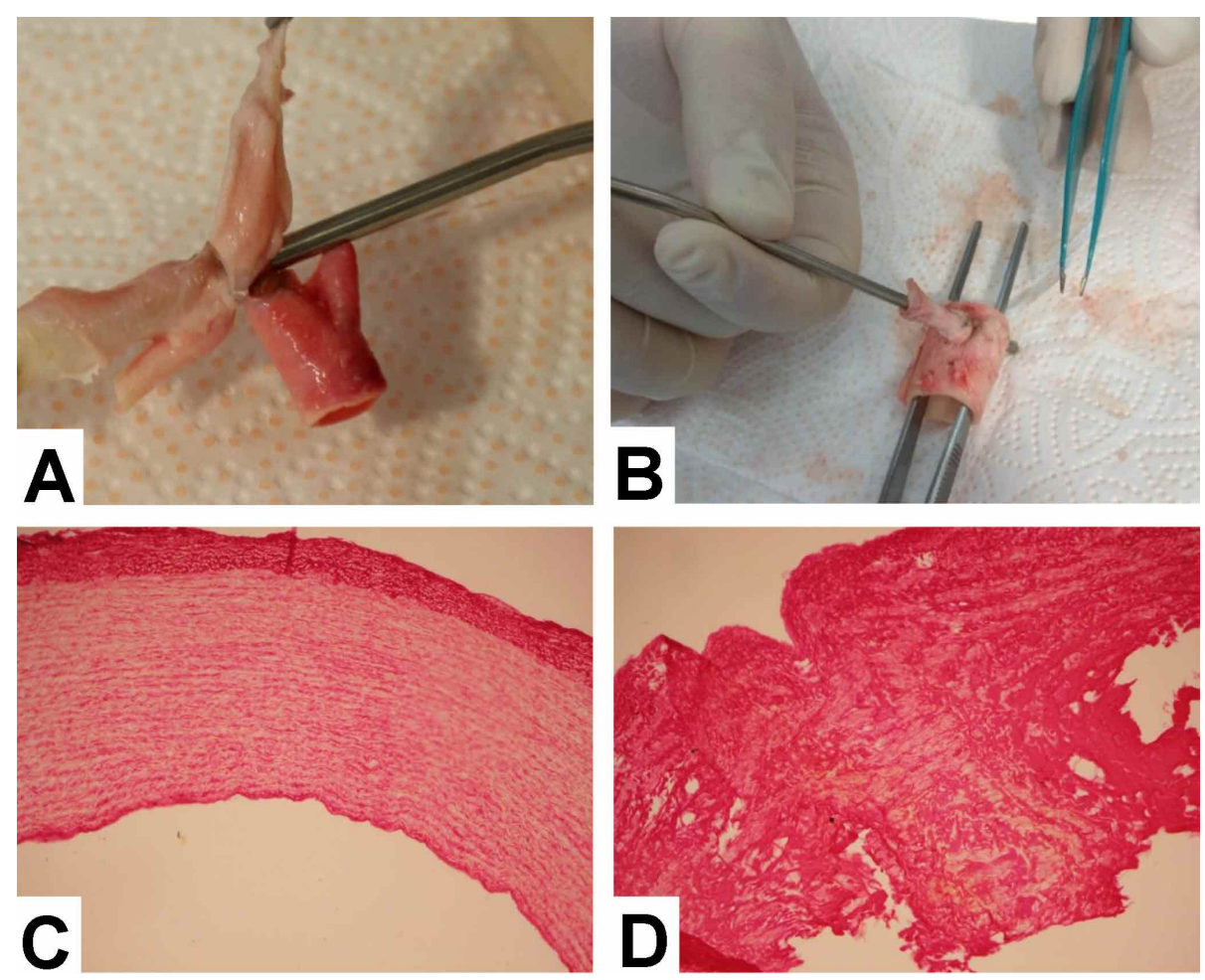

Fig. 9. The results of arterial and venous end-to-side welding: a) the first step of the welding process in the artery and vein; b) the final appearance of the weld; c) intact area of the artery (picrosirius red $\times 100$ ); d) welding area (picrosirius red $\times 200$ ). 
End-to-end venous welding. After welding (Figs. 10a,b), a coagulation area was observed in the vein, which was characterized by the thickening of the blood vessel wall, disorganization of the vascular structural elements and the appearance of a homogeneous acellular matrix in the blood vessel wall (Fig. 10c,d). The tunica media was damaged the most, with a total loss of the cellular elements in this area. The contour of the adventitial membrane was also poorly observed.
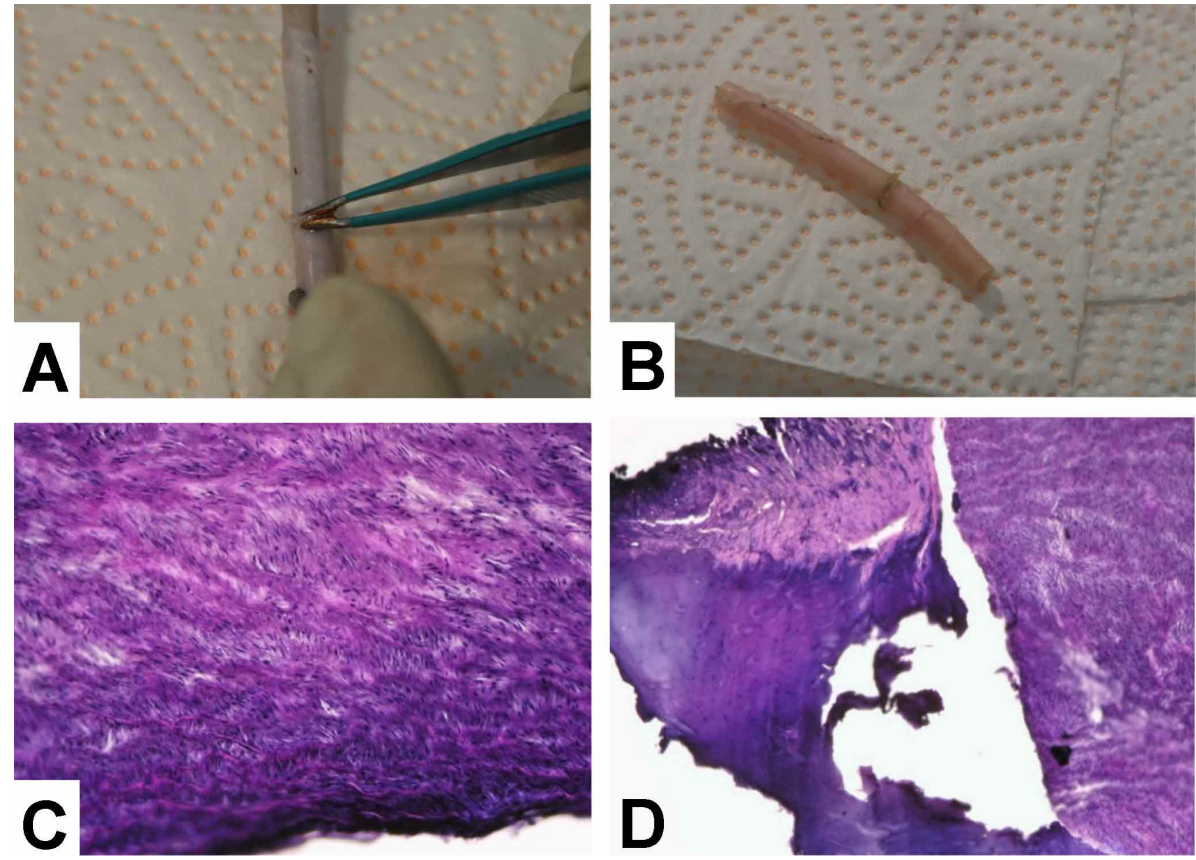

Fig. 10. The results of venous end-to-end welding: a) process of venous welding with electrosurgical forceps; b) final appearance of the welded vein; c) intact area of the vein (hematoxylin-eosin, $\times 200$ ); d) welding area with a homogeneous coagulated matrix (hematoxylineosin, $\times 200$ ).

\section{DISCUSSION}

The technology of electric welding was created based on the scientific research and development results of the staff of the E.O. Paton Institute of Electric Welding of the National Academy of Sciences of Ukraine. The first experimental and further clinical attempts to use electric welding technology in the soft tissues were carried out at the Institute of Experimental Surgery and Transplantology of the National Academy of Medical Sciences of Ukraine and later at other Institutes of the National Academy of Medical Sciences of Ukraine and clinics of higher educational institutions of Ukraine. Foreign specialists were interested in the experience of Ukrainian scientists. This technique is currently used and improved in many countries around the world, such as the United States of America, China, France, Great Britain and others. The interest of surgeons is explained by the fact that due to the tissuepreserving effects of the energy on the operated organ, there is an insignificant destructive effect on the living tissue, which allows for simultaneous incision and coagulation with almost no damage to the morphological structure of the tissue (Han et al.; Muzychenko et al.; Savolyuk et al. 2020). However, many parameters of the use of welding in biological tissues in abdominal, vascular and other types of surgery remain unclear.

The soft biological tissues are composite materials with a wide range of properties of their components. They consist of the cells, connective tissue and biological fluids, which in turn consist of fibrillar and globular proteins, as well as aqueous electrolytes. A dependence of the biological tissue thickness on the specific pressure is essentially nonlinear and is well described by an exponential polynomial of the second order with a correlation coefficient $>0.99$. One of the exponential components seems to reflect a mechanical reaction of collagen-containing, and the other of elastincontaining, morphological structures of the studied organs.

According to the literature (Umanets et al., 2014; Valikhnovska et al., 2020), the dispersion of impedance for the living biological tissues is mainly determined by cell condition and it disappears with their death. The experiments showed that electrolytes, which determined tissue electrical conductivity, and in the absence of the cells, also showed the dispersion of impedance. The nature of the dispersion of impedance depends on the structure of the dielectrics contained in the electrolyte. It is proven that electric welding of the soft biological tissues is performed with a mechanical stress on the electrodes of an order of magnitude greater than that during coagulation. There is an optimal pressure on the electrodes, which ensures maximum strength of the welded junction. When the soft biological tissues are compressed by welding electrodes, their significant 
MUZYCHENKO, P. F.; CHERNYAK, V. A.; SAVOSKO, S. I.; LANKIN, YU. N.; KARPENKO, K. K.; DUBENKO, D. E.; NAHALIUK, YU. V.; ZORGACH, V. U.; MANZUK, T. I.; GYBALO, R. V. \& KOSHEVSKIY, U. I. Morphological assessment of vascular anastomoses performed using high frequency electric welding. Int. J. Morphol., 39(4):1183-1189, 2021.

deformation occurs depending on the type of the tissue (4.510 -fold at a pressure of $11 \mathrm{kgf} / \mathrm{cm}^{2}$ ). A reduction in the thickness of the tissue between the electrodes is mainly due to the displacement of water, the volume of which is reduced 10-30-fold. The amount of protein in the compressed tissue decreases less, namely: 1.4-10-fold. As a result, water content in the compressed tissue is reduced 2-6-fold, and resistivity increases 3-15-fold compared to uncompressed tissues. As the data on the impedance of biological tissues, summarized in the literature on bioimpedance, were obtained for uncompressed tissues, they are absolutely unsuitable for the calculations and computer modeling of welding processes in the soft biological tissues. Changes in parameters are controlled by resistivity and tissue thickness. With increasing pressure, total resistance, on the one hand, increases with increasing resistivity due to dehydration, and on the other hand, decreases due to a decrease in tissue thickness. As a result, with increasing pressure, the resistance first decreases and then stabilizes or even increases slightly. The dispersion of impedance is most evident in unloaded tissues in the frequency range of 0.3-3.0 kHz. For frequencies of 3-300 $\mathrm{kHz}$, the dispersion of impedance for the soft biological tissues is almost independent of the applied mechanical stress. The dispersion of impedance depends both on the cell membranes and all other components of the fluid system, including electrolytes.

The main technological parameter of resistance welding of the soft biological tissues is the current flowing through the tissue. The electrical conductivity of biological tissues depends on the biological fluids (electrolytes) contained in the tissues (which are $55 \%$ of body weight). They are mainly extracellular and intracellular fluids ( $86 \%$ of all body water). In terms of electrical properties, saline solution containing 0.9 $\% \mathrm{NaCl}$ is the closest to the extracellular fluid. Electrical conductivity of the biological tissues is determined by the presence of the ions in the liquid phase. The main contribution to electrical conductivity is made by intracellular and extracellular fluids, blood and lymph. After tissue heating to $100{ }^{\circ} \mathrm{C}$, it is intensively dehydrated due to evaporation. This process consumes more than $80 \%$ of energy and welding time, while coagulation consumes $\sim 10 \%$.

Electrical conductivity in the whole organs is $2-5$ orders of magnitude lower than electrical conductivity of biological fluids. Therefore, after "complete" dehydration, the tissue almost loses its electrical conductivity, heat is no longer released in it and current transmission has no more sense. The tissue of the welded junction is denatured, completely destructured and is a homogeneous mass of collagen, elastin and basic tissue substances with significantly reduced margins between them (Muzychenko et al.; Chernyak et al., 2019b).
During electric welding of the blood vessel walls, a seam is formed between the electrodes consisting of a dense translucent light-brown tissue with a clear margin along the edge of the location of the electrodes. Microscopically, the substance of the electric weld is represented by a homogeneous dense substance formed by coagulated and tightly connected protein structures, the basis of which is the fibrous structure of the blood vessel wall, to a greater extent collagen fibers. The adventitia homogenization area and the smooth muscle fiber coagulation area are observed along the direction from the surface of the electrodes. The main components of the electric weld are collagen fibers, mainly located in the adventitia, and therefore we observe the formation of a strong, dense, homogeneous substance of the weld in these areas. Structural changes in the smooth muscle fibers, located mainly in the media, are characterized by the development of coagulation necrosis. The cellular nuclei and contours are preserved, which indicates a lower strength of the weld in these areas. Small cracks are also found between the fascicles of the coagulation-altered smooth muscle fibers due to vaporization, and they also reduce the strength of the seam. Coagulation-induced changes in the tissues are also observed perifocal from the edges of the electrodes at a distance of 1.0-1.5 mm. However, the contours of the tissue structures and cellular nuclei are clearly observed. Even more perifocal (at a distance of 2-3 $\mathrm{mm}$ ) from the edges of the electrodes, in the arterial walls, focal coagulates and characteristic signs of electromagnetic field impact (rhythm of structures, separation of conductors and dielectrics, polarization of structures with changes in their spatial location) are observed, and the blood vessel walls are thickened.

In conclusion, high frequency electric welding techniques can be used in vascular surgery to create vascular anastomoses. For circular electric welds, modes with voltage (frequency $0.3-3.0 \mathrm{kHz}$ or 3-300 kHz) are sufficient, which should be determined by the morphology of the vessels (thickness, histological type of the vessels, physiological state). Based on the obtained results, the studied techniques may be used in clinical practice due to their advantages over mechanical and manual techniques.

MUZYCHENKO, P. F.; CHERNYAK, V. A.; SAVOSKO, S. I.; LANKIN, YU. N.; KARPENKO, K. K.; DUBENKO, D. E.; NAHALUK, U. V.; ZORGACH, V. U.; MANZUK, T. I.; GYBALO, R. V. \& KOSHEVSKIY, U. I. Evaluación morfológica de anastomosis vasculares realizada mediante soldadura eléctrica de alta frecuencia. Int. J. Morphol., 39 (4):1183-1189, 2021.

RESUMEN: Los estudios de las propiedades de las estructuras y tejidos vasculares durante la soldadura eléctrica son relevantes, en particular los cambios morfológicos directos en las paredes de los vasos sanguíneos en las áreas de los procesos de 
soldadura. En este estudio se utilizaron venas perforantes, venas femorales, parte abdominal de la aorta, vena cava y venas perforantes porcinas de los miembros. Realizamos soldadura eléctrica de extremo a extremo de la parte abdominal de la aorta, soldadura eléctrica de extremo a lado venosa, soldadura arterial y venosa de extremo a arteria del lado venoso, soldadura eléctrica de extremo a extremo venoso, así como lumen arterial y venoso. Los resultados de los estudios histológicos mostraron la formación de una matriz de proteína acelular coagulada, representada por estructuras fibrosas de proteínas desnaturalizadas no organizadas. Se formaron lagunas como resultado de la evaporación del agua del tejido biológico en el área de la coagulación del tejido vascular, En el área perifocal de la unión soldada, la reducción celular ocurrió sin necrosis ni carbonización. Los datos obtenidos confirman la seguridad de la soldadura eléctrica de alta frecuencia de los vasos principales y la perspectiva de uso clínico de estas técnicas.

PALABRAS CLAVE: Vasos sanguíneos; Anastomosis; Tecnologías de soldadura de alta frecuencia; Coagulación; Estructura; Histología.

\section{REFERENCES}

Chernyak, V. A.; Dubenko, D. Y.; Gumenchuk, O. Y.; Melnyk, M. A.; Karpenko, K. K. \& Levon M. M. Experimental Single-Step Electric Welded Connection of Vessels. Zurich, 20th EVF Annual Meeting from 27 to 29 June 2019, 2019a. pp.42.

Chernyak, V. A.; Karpenko, K. K.; Gichka, S. G.; Dybgaluk, S. V.; Muzychenko, P. F.; Golinko, V. M.; Dubenko, D. E. \& Udovichenko, V. V. Welding Technology in Vascular Surgery. Krakow, 20th EVF Annual Meeting from 25 to 27 August 2019, 2019b. pp.52.

Han, S.; Cai, Z.; Ning, X.; He, L.; Chen, J.; Huang, Z.; Zhou, H.; Huang, D.; Zhang, P. \& Li, Z. Comparison of a new high-frequency electric welding system for intestinal closure with hand-sewn in vivo pig model. J. Laparoendosc. Adv. Surg. Tech. A, 25(8):662-7, 2015.

Marinsky, G. S.; Chernets, O. V.; Tkachenko, V. A.; Grabovsky, D. A.; Podpryatov, S. E.; Lopatkina, E. G.; Podpryatov, S. S.; Tkachenko, S. V. \& Gichka, S. G. Bench research of high-frequency electric welding of biological tissues. Paton Weld. J., 12:41-5, 2016.

Marynskyi, G. S.; Lopatkina, K .G.; Chernets, O. V.; Podpryatov, S. E.; Tkachenko, V. ?.; Belousov, I. O. \& Vasylchenko, V. A. New algorithms of high-frequency welding of biological tissues. Paton Weld. J., 2(2):147, 2021

Muzychenko, P. F.; Chernyak, V. A.; Marinskiy, G. S. \& Volnyanskaya, E. D. Restoration of tendons, using electric welding - A new step in traumatology. Klin. Khir., (12):64-6, 2016.

Podpriatov, S. S.; Podpryatov, S. E.; Gichka, S. G.; Hetman, V. G.; Makarov, A. V.; Marinsky, G. S.; Lebedev, O. V.; Tkachenko, V. A.; Chernets, O. V.; Chvertko, N. A.; et al. The features of electric welding colorectal anastomosis creation in experiment and clinics. Rep. Vinnytsia Natl. Med. Univ., 22(3):532-7, 2018.

Savolyuk, S. I.; Khodos, V. A.; Herashchenko, R. A. \& Horbovets, V. S. Comparative evaluation of the results of surgical treatment of acute ascending thrombophlebitis of the great saphenous vein using the endovascular high-frequency welding technique and traditional technique. Wiad. Lek., 73(4):638-41, 2020.

Tryliskyy, Y.; Kebkalo, A.; Wong, C. S.; Rublenko, S.; Rublenko, M.; Inytskiy, M.; Negria, I. \& Hordovskiy, V. Safety analysis of endoscopic haemostasis using a high-frequency live tissue electric welding device - EKVZ300 PATONMED. Prz. Gastroenterol., 13(3):234-7, 2018.
Umanets, N.; Pasyechnikova, N. V.; Naumenko, V. A. \& Henrich, P. B. High-frequency electric welding: a novel method for improved immediate chorioretinal adhesion in vitreoretinal surgery. Graefes Arch. Clin. Exp. Ophthalmol., 252(11):1697-703, 2014.

Valikhnovska, K. G.; Savytska, I. M.; Nataliya, P. R. \& Voitiv, Y. Y. Experimental studies of the effect of electrosurgical and standard techniques on pancreatic restoration. Wiad. Lek., 73(5):909-13, 2020.

Wegner, K. A.; Keikhosravi, A.; Eliceiri, K. W. \& Vezina, C. M. Fluorescence of picrosirius red multiplexed with immunohistochemistry for the quantitative assessment of collagen in tissue sections. J. Histochem. Cytochem., 65(8):479-90, 2017.

\author{
Corresponding author: \\ Savosko Serhii, PhD \\ Associate Professor \\ Department of Histology and Embryology \\ Bogomolets National Medical University \\ T. Shevchenko Boulevard, 13 \\ Kyiv \\ UKRAINE
}

E-mail:s.i.savosko@gmail.com

Received: 19-04-2021

Accepted: 04-06-2021 